\title{
Beyond the Conflict: Religion in the Public Sphere and Deliberative Democracy ${ }^{1}$
}

\author{
Elsa González*, José Felix Lozano** and Pedro Jesús Pérez ${ }^{* * *}$
}

Abstract: Traditionally, liberals have confined religion to the sphere of the 'private' or 'non-political'. However, recent debates over the use of religious symbols in public spaces, state financing of faith schools, and tax relief for religious organisations suggest that this distinction is not particularly useful in easing the tension between liberal ideas of equality among citizens and freedom of religion. This article deals with one aspect of this debate, which concerns whether members of religious communities should receive exemptions from regulations that place a distinctively heavy burden on them. For supporters of exemptions, protection for diverse practices and religious beliefs justifies such a special treatment. For others, this is a form of positive discrimination incompatible with equal citizenship.

Drawing on Habermas' understanding of churches as 'communities of interpretation' this article explores possible alternative solutions to both the 'rule-andexemption' approach and the 'neutralist' approach. Our proposal rests on the idea of mutual learning between secular and religious perspectives. On this interpretation, what

\footnotetext{
${ }^{1}$ This article draws on research carried out with the support of the EuroEthos Research Project Project, funded under the European Commission's $6^{\text {th }}$ Framework Programme. Thanks to two anonymous referees for helpful comments on an earlier draft.

* Elsa González. Universitat Jaume I, Department of Philosophy and Sociology, Avda. Sos Baynat s/n, 12071 Castellón, Spain. [esteban@fis.uji.es]

** José Felix Lozano. Valencia Politechnic University. Department of Engineering Projects. Valencia. Spain. [jlozan@dpi.upv.es]

Pedro Jesús Peréz. Valencia University. Departmental Section of Moral Philosophy. Spain. [P.Jesus.Perez@uv.es].
} 
is required is, firstly, generation and maintenance of public spaces in which there could be discussion and dialogue about particular cases, and, secondly, evaluation of whether the basic conditions of moral discourse are present in these spaces. Thus deliberation becomes a touchstone for the building of a shared democratic ethos.

Keywords: Religious neutrality, Religious beliefs, Religious exemption, Deliberative democracy, Discourse Ethics, Public Sphere.

\section{Introduction}

Since the 1980s, the debate over the role of religion in liberal democracy has gained renewed attention in both theory and practice. Several governments in Europe and the US have granted religious organisations financial support, tax relief and sometimes even exemption from universally applicable laws such as antidiscrimination laws and mandatory education (Minow 2007). Politicians, as well as political theorists, grapple with two main issues: the role and scope that religion should have in public spaces, and the legitimacy of state intervention in regulating the life of religious organisations with regard to freedom of association. In particular, a persistent concern is whether rules tailored for religious groups and organisations lead to discriminatory practices with respect to non-religious citizens and organisations (Barry 2001). Cases debated at the level of public opinion, such as the wearing of the Islamic headscarf in France, Spain and Holland (Galeotti 1993), or the request by Sikhs in the UK and Canada to be permitted to wear traditional dress (Levy 1997), serve as examples of the deep conflict generated by requests for differential treatment on religious grounds. Why should religion be a source of special treatment in pluralistic societies? What are the features of religion and religious affiliation that justify differential treatment and departure from universally applied rules? 
In order to answer these questions, it is necessary to widen the perspective and understand the role assigned to religion by liberals. In particular, in the section Liberals and Religion we identify a classical liberal position that relegates religion to the realm of the private and excludes it from the sphere of the public and political (Rawls 1999; Barry 2001). A more positive view on religion, explored in the following section, is offered by those authors that we call 'reformists'² (Audi and Wolterstorff 1997; Bader 1999 and 2003; Weithman 1995). These promote an approach of 'accommodation' and 'structural integration' of religion in the democratic political space. Their argument is based on two propositions: criticism of traditional separation between the private and the public; and the idea that religious traditions can make a valuable contribution to the public sphere.

We propose a more radical critique of the private/public distinction. The article supports a Habermasian deliberative democracy approach to the issue of exemptions on religious grounds by contrasting it on the one hand with a liberal approach, and on the other hand with a reformist perspective. Following Jürgen Habermas' (2008a) theory of deliberative democracy, we identify churches and religious groups as' "interpretative communities" which can be trained to present arguments regarding public matters, with the sole condition that they be universally comprehensible and plausible (see the penultimate section on Complementary learning processes). Within this framework, in the concluding section, we develop a possible answer to the question of whether religious groups and organisations should, at least in certain cases, be granted differential treatment. On our account, what is required is: firstly, generation and maintenance of public spaces to provide a platform for discussion and dialogue about concrete cases; and, secondly, evaluation of whether the four basic conditions of moral discourse are present within these spaces. That is, evaluation of whether the demand for an exemption would stand up to: 1) an open public discussion in which all affected parties could participate; 2) a situation in which all interlocutors would be on equal footing while presenting their arguments; 3) a situation in which all persons express their sincere ideas; and 4) the requirement that there be no other coercion - that is, that the driving force truly be that of the best argument.

\footnotetext{
${ }^{2}$ We use 'reformist' because their proposals are intended to develop the ideals of membership and participation without relinquishing the core presumptions of liberal democracy. Thus, behind the shared reformism, lie different political philosophical backgrounds, such as communitarianism or republicanism.
} 
Should a demand for a concrete exemption pass this test, it would imply neither a prejudice nor a danger to deliberative democracy and could be accepted. Indeed, it would strengthen deliberative democracy insofar as it would open up a space for contestation and re-discussion of commonly accepted rules. We shall argue that differential treatment for religious groups can be justified if we adopt a more positive view of religion as a source of motivation and as a space within which to cultivate lively contexts for the development of ideas and reasons that can contribute to the public life. Exemptions are often necessary to create and maintain these communities of interpretation.

\section{Liberals and religion}

The issue of possible religious exemptions to universally applicable laws highlights key sites of contestation about the nature of the liberal polity - both among liberals and their critics. Thus the tension between religious freedom on the one hand and the equality of citizens on the other - and the very notion of the separation of church and state - raise questions about the very self-understanding, and the viability, of a liberal democracy. No consensus exists as to how these questions ought to be negotiated. Consequently, political responses to claims to religious exemption have been plural both in theory and in practice.

Generally speaking, within the liberal tradition, demands for exemptions by religious groups to the fulfilment of certain laws have been met with unambiguous negatives (Marshall 1990, pp. 386-400). ${ }^{3}$ This can be attributed to the need to respect those principles, including equality of citizens and the separation of Church and State, which regulate co-existence within liberal democracies. However, this position is tempered by other considerations related to the nature of religion. An examination of all

\footnotetext{
${ }^{3}$ Some liberal authors have also recently drawn attention to the relevance of religion. In particular, BouHabib (2006) critically characterises religion as a 'basic good' or an 'intense preference'. He argues that religious conduct can be a 'derivative good', with its value stemming from the integrity of the religious person. Liberal multiculturalism also concedes that some cultutal and religious exemptions are necessary in order to preserve other values such authonomy and equal respect. All these perspective register a tension between 'public' obligations and 'private' obligations deriving from religious membership.
} 
of these elements will assist in understanding the positioning of both liberals and their critics (reformists) on this issue. It will also facilitate the positioning of our proposal on a middle ground, discussed in this article and based on Habermasian thought, which in turn is grounded in a proposal of deliberative democracy rooted in discourse ethics. ${ }^{4}$ Habermas' viewpoint retains a reformist position but preserves the boundaries of liberal thought.

Liberals tend to tackle the presence of religion in the public sphere by appeal to a polarised distinction between the "public" and the "private". The 'public' incorporates decisions concerning coercive acts, including those aspects of society which are under state control and therefore tied into the public interest (Hollenbach 1993, pp. 880-888). The 'private' concerns those aspects of individual lives which lie beyond rightful state control, such as family, business, leisure time and conception of the good. The purpose of this distinction is twofold. First, it establishes a separation between the State and religion in such a way that the Government cannot base decisions on the dictates of any particular religion and citizens should not base public participation on religious motives. The second intention is further reaching: that of confining religious beliefs to the believer's own conscience. Thus from this angle, interpersonal relations in our pluralist societies should be viewed through a secularly-based principle of equal treatment of persons. ${ }^{5}$ In this context, religious exemption would be unacceptable, for two reasons: it would presume the intervention of religious convictions in an area where they have no place; and, more to the point, religious exemption in itself is understood to imply unfair discrimination of citizens (Marshall 1990, p. 404).

Liberals' concern to exclude religion from the public sphere, as well as their difficulty to justify religious exemptions, reflects the pejorative conception of religion held by many liberal theorists. This may be reduced to two essential elements: its characterisation as a cause of conflict among citizens, and its inconsistency with reason and therefore unintelligibility. We will begin with the first element.

\footnotetext{
${ }^{4}$ See Noonan 2005, pp. 103-110 for an overview of the characteristics of a deliberative democracy rooted in discourse ethics.

${ }^{5}$ This dichotomy between public and private spheres would be rejected both by defenders of religion in the public realm and by Habermas, through deliberative democracy, as we shall see later.
} 
Since the Reformation, religion in the public sphere has been perceived as a threat to social peace in the context of moral pluralism (Audi 1997, p. 34). Its admission to the public sphere meant the submission of political powers to the dictates of a specific church with the nefarious consequences this implied. For this reason, it seemed that the best way to avoid religious conflict was to deprive religion of any influence in public life, leaving it to the realm of the individual conscience and private relations among believers (Locke 1999, p. 79). Thus, religion was privatised, following its expulsion from the public arena and reclusion within the personal conscience. ${ }^{6}$

Liberals today continue to maintain this idea. Rawls, for instance, introduces the notion of 'civil duty'. This requires people to vote not according to the dictates of their comprehensive doctrines or personal interests but only from the perspective of the common good, thus avoiding using the State's coercive power to impose their own comprehensive views (Rawls 1996, p. 251). Similarly, Audi defends the claim that secular motivations may be acceptable for all citizens, while religious convictions are always a cause for confrontation. Thus, anyone supporting a measure solely on religious grounds would be imposing his conception of the good on others (Audi 1989, p. 283). However, this argument is criticised by revisionist authors such as Habermas (2008a) for representing an attitude incapable of recognising the positive value of religion within the public realm.

Let us turn now to the second element of the liberal conception of religion: an appeal to the unintelligible character of religion. At the heart of the liberal argument lies a dichotomy between two clearly defined spheres: that of practical reason and that of revealed faith. The former is a mutually accessible sphere, being common to all rational citizens. In contrast to this accessibility, revealed religion constitutes a sphere which is per se inaccessible, given that it starts from experiences which are alien to common reason, such as faith or theophany (Greenawalt 1990, p. 1031). Thus, practical reason and faith constitute two mutually exclusive realms (Kant 1999, B XXIV-XXVI).

\footnotetext{
${ }^{6}$ The reclusion of religion to the conscience of the believer was in fact a triumph of the Protestant Reformation, which decided, based on theses such as the free interpretation of the Scriptures, that the relation between God and man was a direct one, through one's conscience, and not through an institution or hierarchy, as held by Catholicism.
} 
As a matter of fact, on the liberal view, the rational and the intelligible are assimilated within the realm of the secular. Religion, by contrast, is regarded as irrational and unintelligible (Audi 1997, p. 17). Accordingly the secular is seen as accessible or intelligible to anyone, including believers. By contrast, the religious one is opaque to reason and cannot be understood by other persons (Bird 1996). Thus, they cannot be admitted within the public sphere. This attempt to deny all cognitive value to religious expression poses a problem for deliberative democracy, as it constitutes an impossible position within the framework of post-secular society, to use Habermas' terminology.

The above account should shed light on why religion has been treated with special cynicism by liberal thinkers, and its exclusion by them from the public realm. On the one hand, given that religious motivations are always sectarian, they must remain relegated to the realm of the private (Bradley 1991, p. 317). On the other hand, religion, unlike secular philosophies, was considered alien to the shared dominion of reason. Thus, claims based on religious convictions could never be subject to public corroboration, which was the minimum needed to obtain legitimacy within the context of pluralism.

From the liberal viewpoint, what makes religions special is that they are sources of conflicts and, accordingly, must remain outside the configurative procedures of public and political space. This is because claims that are not universal, and cannot be the object of agreement in society, do not merit a place in the context of liberal public justification. Thus, traditionally, the liberal position is that religions ought not to enjoy any exemption from universally applicable rules.

\section{The value of religion in the public sphere}

Exemptions to the rule, conscientious objections and civil disobedience are often framed in relation to personal matters of conscience, on the one hand, and the positive norms of the political community, on the other. It has often been thought that the question: 'When are we justified in disobeying law?' (Jones 2004, p. 336) can be answered in liberal democracy by the relegation of religious and ethical beliefs to the private sphere, and by defending the priority of the right over the good (Rawls 1971). 
Faced with these liberal arguments, in this section we identify two possible ways, each with different implications, to concede that there is value in religion. The first is to take the view of certain non-liberal authors, reformists, who argue from diverse philosophical starting points that some exemptions can be granted in order to guarantee freedom of speech and expression, and more in general to enable participation of religious people in the public life. Another perspective is provided by deliberative democracy and based on discourse ethics and makes possible justifying some exceptions in order to provide religious organisations with the means for becoming 'communities of interpretation'. Its proponents include Habermas (1996, 1998) and Cortina (1993, 2001).

Some reformists, including Bader, Taylor, MacIntyre and Weithman, stress that religion is a substantial part of social reality. Elimination of religion from the public sphere would, they argue, constitute an injustice which would lead to further damage rather than to any good. For Weithman, the institutional principle of political neutrality requires that one: 'leave... aside very important questions about what else a commitment to the ideals of freedom and democracy requires' (Weithman 1991, p. 54). Bader (2003) affirms more radically: 'The more or less radical exclusion of religious reasons and arguments from public debate and politics has extensively been criticised as morally arbitrary, unfair, incompatible with freedoms of communication, and practically counterproductive' (Bader 2003, p. 4).

The idea is that treating people justly does not require abstraction from all of their cultural and religious particularities. Rather, it means taking them into consideration in an impartial manner. Authors who opt for a proposal of 'accommodation' or 'structural pluralism' include: liberal protestants such as Steven, Smith and Wolterstorff; liberal Catholics such as Perry, Glendon, and Novak; and even defenders of the egalitarianism of democratic institutional pluralism, such as Bader. All these streams of thought are strongly critical of the liberal 'separationist' vision and offer political theories which better respond to the complex relationship between religion and society.

From this perspective, the question of whether determined religious groups are justified in not obeying laws which conflict with their beliefs would have a positive, prima facie response. Jones states: 'A society might recognise the difficulty faced by these of its citizens and circumvent it by exempting them from the demands of the 
relevant law.' (Jones 2004, p. 328) He cites as an example the exemption made for Sikhs in the United Kingdom, allowing them not to wear helmets and permitting them to carry bladed weapons in public.

However, Jones’ responses prompt a deeper discussion of the view of religion set out by standard liberalism. For example, Bader offers the following serious criticisms of the central precepts of liberalism as depicted in the previous section.

Firstly, the liberal model of a 'well-ordered society' in which free, rational citizens decide how to organise themselves according to an ideal that clashes with liberal democratic practices. On this account, the difference between constitutions, states and liberal democratic societies is not taken into account. This confusion between the ideal model and the actual states is apparent in certain liberal ideas, such as consolidation of discrimination and inequality as 'difference-blind neutrality'. In the real world, states are not, de facto, neutral with respect to organised religions, and therefore any intended (impossible) neutrality would lead to discrimination against minority religions.

Secondly, the liberal model assumes too much consensus. According to Bader (1999) and Gutmann and Thompson (1990), the liberal conception undervalues moral pluralism. Liberalism transmits the illusion that consensus may be reached by delving into the basis of moral conflicts or by raising ourselves to the second-order principles. However, in reality, discrepancies linked to political and moral matters are a serious issue for citizens, not only for jurists and moral philosophers. It is truly difficult to reach a consensus on morally controversial topics such as abortion, genetic research or euthanasia, although decades have been spent debating them.

Thirdly, one of the more serious and far-reaching critiques of liberalism concerns its two main dichotomies: public versus private and secular versus religious. The critique would justify renouncing the neutrality of a liberal democracy and giving a public role to religion. Liberal strategies to separate the public from the private, the political from the moral, and the secular from the religious, and to purge public reason of illegitimate influences are described by Bader as 'unfair, exclusionist, unachievable, counterproductive, or self-defeating' (Bader 1999, p. 601). These distinctions do not function in the real world. In the worst cases, these liberal strategies favour the powerful and those with the greatest resources. Furthermore, the pretence of neutrality and the 
exclusion of religion from public life ignores the valuable contribution made by religions to public affairs throughout history (Weithman 1991).

Fourthly, liberals have forgotten the importance of virtues. As with the previous argument, the point can be made that religions play a key role in the development of character and motivating moral action. In contrast to the 'coldness' of rules, processes and duties, religious traditions have offered meaning, a sense of belonging and an interest in transcendence.

When it comes to supporting democracy, what matters are the contributions that can be made to questions of rights, culture and practical attitudes, not whether these stem from a religious or a secular source ${ }^{7}$.

One of the key principles of liberal democracy is freedom of conscience, of opinion and of expression. If we link this belief to the realm of religion we can identify the 'freedom to' believe and the 'freedom from' state intervention in religious matters. In many cases, guaranteeing the positive freedom to believe in or practice a religion implies state intervention, which may in turn lead to conflict with the aspiration for religions freedom from state interference (Bader 2003, p. 275). Furthermore, it is a duty of the State to protect believers from their 'own' religious groups, associations and leaders. As Quong asks: 'What happens when a minority group says, 'this practice is important to our identity’, but intra-group minorities dissent from the majority opinion?' (2004, p. 43)

This has important implications for how we should regard questions of exemption, conscientious objection, and even civil disobedience. None of these imply a rejection of democracy, but ought to be understood as a manifestation of the demos. Each constitutes an exercise in public deliberation and in that sense forms part of the democratic process in its broadest sense (Jones 2004, Smith 2004). In fact, the radical expulsion of religion from public space, as proposed by some liberals, would work against one of the basic principles of deliberative democracy (Smith 2004), given that it would involve 'de facto' exclusion of some people from public debate. If individuals are

\footnotetext{
${ }^{7}$ Bader (1999, p. 602) expresses this idea forcefully: 'The important thing, given the priority of democracy, should not be whether arguments are religious or secular but whether arguments, attitudes and practices are compatible with the principles, rights, culture, virtues, and good practices of social, democratic constitutionalism.'
} 
permitted to participate but are hindered from making proposals based on their deep, sincere religious convictions, they will 'feel' excluded from the deliberation. Smith (2004, p. 369) argues that there may be situations in which the prohibition of certain points of view and relevant opinions may make civil disobedience appropriate.

Accordingly, reformist authors (particularly Bader) argue that religious beliefs and organised religions must participate in public debate. Drawing on Richard Rorty, they propose a formula of 'priority for democracy'. 'Priority for democracy should not be confused with a secularist strategy to purify public reason from religious arguments.' (Bader 1999, p. 602) This argument implies that the principles, institutions, cultures, virtues and practices of a liberal democracy have priority over the fundamentals of liberal democracy, whether religious, philosophical or scientific (Bader 2003). ${ }^{8}$

On this line of argument, faith-based reasons may be considered essential for the construction of the public sphere, and even justified for the legitimate configuration of the political space. Nonetheless, the manner in which both secular and faith-based reasons may be articulated needs to be clearly defined. We need to ask such questions as: 'Is there a place for religious beliefs in the configuration of the public sphere in democratic societies?', and if so: 'Do religious beliefs sometimes require special treatment in a pluralistic society?' To put it another way: 'Should religious groups at least in certain cases be exempt from civil rights laws?'

A reconsideration of the value of religion, drawing on discourse ethics, with a corresponding understanding of democracy as deliberative democracy, is, in our opinion,

\footnotetext{
${ }^{8}$ We wish to insist that following this argument would in no way imply the claim that religious norms and traditions must be respected per se and that the State must abstain from interfering in all religious practices. Of course, some of these practices must be considered manifestations of freedom of conscience which may clash with other basic political rights, but both are relevant for citizens and it is difficult to prioritise one over the other (Weithman 1995, p. 32). Here it is crucial to distinguish between practices such as the consumption of peyote in some religious Amerindian ceremonies or the ritual sacrifice of animals, which pose no harm to other people, and practices which attack the dignity and basic rights of people. Religious practices which lead to domestic violence, genital mutilation, sexual abuse or collective suicide, for example, must be prohibited by the State. 'Here, criminal law should step in: priority for liberal democracy must be strong enough to legitimize public scrutiny and interference to sanction these practices effectively.' (Bader 2003, p. 277).
} 
a good path on which to find well-rooted answers to these questions. ${ }^{9}$ The following section deals with this perspective.

\section{Complementary learning processes between secular and religious beliefs}

The key idea of deliberative democracy does not so much concern how the political space is configured, as how it ought to be configured in order to establish moral legitimacy. For this reason it includes two principles. ${ }^{10}$ Firstly, the principle of universalisation [U]: 'A norm is valid when the foreseeable consequences and side effects of its general observance for the interests and value-orientations of each individual could be jointly accepted by all concerned without coercion.' (Habermas 1998, p. 42) Secondly, the discourse principle [D]: 'Only those norms can claim validity that could meet with the acceptance of all concerned in practical discourse.' (Habermas 1998, p. 41)

As we may observe, procedures in which norms are legitimised are crucial for a deliberative democracy. It would be unacceptable to leave aside religiously-based arguments, because what matters is guaranteeing a process from which a valid norm will emerge.

This proposal for deliberative democracy draws on liberal and republican conceptions (Habermas 1996, pp. 287-387) of the State and civil society, both of which are indispensable for the ethical configuration of the political arena. Habermas argues that liberal and the republican understandings of politics both commit two errors which are overcome by the deliberative democracy model. Firstly, they uphold the philosophical

\footnotetext{
9 To address the response which has emerged from critical theory, we focus on Habermas' (1996, 1998, 2008a, 2008b) and Cortina’s (1993, 1995, 1998, 2001) works and thought.

${ }^{10}$ With the U principle, which establishes the conditions for discourse, one may distinguish norms which are morally valid, as each affected subject is obliged to accommodate himself to and understand the perspective of others before expressing his own interests. In other words, each must enter into dialogues whose objective is understanding and in which the participants take one another into consideration as valid interlocutors. Now, as we enter the territory of configuring a morally legitimate political space, one must take into account not only this principle, but also that in which juridical-political norms comply with the $\mathrm{D}$ principle. This then establishes that it is the actual participants in the discourse, those affected by the moral norm in question, who take on the role of protagonists through their active participation in the dialogue aimed at understanding. At the same time, one affirms that the types of reasons or judgements emitted are those which must be examined in each process of debate.
} 
model of the subject's conscience, ${ }^{11}$ and, secondly, they confuse the public with the political-state sphere. $^{12}$

The key issue is to establish communicative conditions in the political process. Only in this way can one expect to produce rational results, as the process is deliberative throughout. Precisely these communicative conditions would permit the establishment of a framework from which to sketch the role religious groups could play in configuring the public sphere, as well as providing an insight into their role in shaping the political and juridical space.

In his last articles, Habermas addresses the theme of religion (2008a, 2008b), making two relevant and convincing points. ${ }^{13}$ Firstly, religion has the right to make itself heard not only publicly but also politically. Secondly, democracy must listen to this voice, for the good of politics. ${ }^{14}$ His position, in Conill's words (2007, p. 573), 'now favours the line of those who have defended a hermeneutic articulation among reason and religion'. These include Cortina (1995, 1998, 2001), who employs the same presuppositions of discourse ethics theory.

The starting point lies in recognition of our location in a post-secular society with three distinctive characteristics. The first is that the context is increasingly secular, whilst at the same time there is a continual presence of religious communities. The second is that religious communities functionally contribute to society insofar as they

\footnotetext{
${ }^{11}$ The error here lies in considering that any interest is true and valid simply by virtue of being 'mine' or 'ours'. For both models of political philosophy, the interest is a given. They forget how these interests were constructed. However, as Mead affirms, any process of individuation is a process of socialisation (Habermas 1972, 1975). Therefore, if the interests have been socially, culturally, or religiously constructed, the political sphere ought to incorporate deliberation concerning them, given that politics is inherent in the processes through which these interests have been formed (Habermas 1996, 1998, pp. 239-264).

${ }^{12}$ The republican concept of democracy is particularly vulnerable to this error, as it stems from the idea of a society which can self-organise as a whole. This overlooks the elements of social and cultural pluralism present in society, which ought to be seriously considered given that the interests and values intrinsic in such pluralism may conflict within the same community without any perspective for achieving consensus. One must not forget that the politically established right needs to be considered legitimate and 'must be at least in harmony with moral principles that claim a general validity that extends beyond the limits of any legal community’ (Habermas 1998, p. 245).

${ }^{13}$ For the discussion on the Habermas's position about the religion role and treatment in a Postsecular Societies see for example the Journal Constellations. 14 (2) with articles from Chambers (2007), Cooke (2007) and Lafont (2007).

${ }^{14}$ It is important to mention here that his position had previously been ambivalent, vacillating and on occasions ambiguous with regard to the relation between religion and reason. See Habermas 1987.
} 
reproduce desirable motivations and attitudes. The third is that a sense of mutual learning has emerged asynchronically between 'religious' and 'secular' mentalities, creating a space for the 'modernisation of the public conscience'. Accordingly, it has become necessary that 'both sides can... take each other's contributions to controversial public debates seriously for cognitive reasons as well, assuming that they share an understanding of the secularization of society as a complementary learning process' (Habermas 2008a, p. 111).

Thus there is no eliminatory relationship between religious and secular attitudes, but rather one of compatibility. As Cortina (1995, p. 13) argues: '(I)t is possible to be a believer and a citizen and not only is it possible, but it is necessary.' To put it concretely, the post-secular conscience recognises that 'the public conscience is composed of secular and religious traditions which mutually fertilise and transform one another' (Mate 2008, p. 31). Herein lies the importance 'complementary learning', in the process of which the secular person who wants the believer rationally to value his points of view must simultaneously recognise his interlocutor as 'not wholly irrational's in his own views. Movement is needed on both sides: by the believer who must 'determine the relation between faith and knowledge self-critically from the perspective of secular knowledge', and by the non-believer who must concede 'an epistemic status as not simply 'irrational' from the perspective of secular knowledge' (Habermas 2008a, p. 112).

Using the logic of this concept of deliberative democracy, based on discourse ethics, a series of points can be raised regarding the liberal and reformist arguments presented in this article. These arguments focused on two possibilities: i) holding to the 'rule' which applies universally with no exemptions or ii) conceding some exceptions when these are necessary to enable an active role for religious groups in the public and political realm.

In what follows we propose a comparison between Habermas's understanding of religion, and the liberal and reformist positions.

Three main points of agreement emerge between liberals and proponents of this particular reading of deliberative democracy. Firstly, within the political sphere, holders 
of religious viewpoints must make the effort to translate their religious beliefs into a language which is secular, common and accessible to all. Secondly, the ways of life and customs of believers and non-believers must be respected by the State insofar as they are compatible with the Constitution. Thirdly, democracy, as based in enlightened thought, must incorporate a critical, and self-critical, capacity, in order to maintain the necessary civic solidarity and, correspondingly, a shared value ethos and a 'common denominator of values' (Habermas 2008a, pp. 120-124).

The areas of agreement with non-liberal (or reformist) arguments can also be reduced to three key points. Firstly, historically, religion has played not only a negative role but also an extremely important positive one in the defence of democracy and human rights. This cannot be neglected. Secondly, the liberal position is asymmetric in demanding that the believer constantly separate his religious from his secular beliefs. This demand is too burdensome, as 'many religious citizens would not be able to undertake such an artificial division within their own minds without jeopardizing the pious conduct of their lives’ (Habermas 2008a, p. 127).

Therefore: 'The liberal state must not transform the requisite institutional separation of religion and politics into an undue mental and psychological burden for those of its citizens who follow a faith. It must of course expect of them that they recognise the principle that political authority is exercised with neutrality towards competing world views... But all that is required here is the epistemic ability to consider one's own reflexively from the outside and to relate it to secular views.' (Habermas 2008a, p. 130)

The third point articulates a position shared by various key authors: religious traditions possess a potential for knowledge, access to the truth, creation of identity and meaning, which must not be avoided in democratic states. ${ }^{15}$ Aside from their functional and motivational value, their content is of great importance. This is especially so given that 'it is also in the interest of the constitutional state to conserve all cultural sources that nurture citizens' solidarity and their normative awareness’ (Habermas 2008a, pp. 111). Therefore, a liberal democracy 'must not discourage religious persons and

\footnotetext{
${ }^{15}$ Martha Minow too takes this line (2007, p. 825).
} 
communities from also expressing themselves as such in the political arena, for it cannot be sure that secular society would not otherwise cut itself off from key resources for the creation of meaning and identity’ (Habermas 2008a, p. 131).

Having identified this common ground, it is important also to indicate where discrepancies appear. There are five main points of disagreement with liberals. Firstly, Habermas believes that the full effort of translation into a language which is accessible to all should not be required for debate in the public sphere. Rather, he believes that, religious discussion within this space could take place at less cost, as suggested by nonliberal or revisionist arguments. Thus, Habermas (2008b) specifies that it is impossible to prevent the Church from acting 'as an interpretative community' - that is, expressing its position in the deliberative phase - but adds that this will succeed only if religious opinions are translated into 'comprehensible and universally plausible arguments'.

The second point of disagreement lies in Habermas' insistence that at no point should the State 'assign its citizens duties incompatible with their way of life as believers', and that the State must respect the lifestyles and customs of believers.

The third point of divergence arises when Habermas suggests that, although the liberal democratic model possesses the resources to establish, maintain and defend a common, shared democratic ethos, the motivational and functional resources of religion may be of great assistance in reviving or supplementing the deficiencies present in its realisation. A liberal democracy, faced with certain conflicts, cannot demand the necessary political virtues, but can merely suggest what would be the best, or the most desirable conduct. In this sense, Habermas identifies a 'motivational deficit' in liberal democracies incapable of inciting political and civic action.

The fourth point of conflict is that liberals reject the role granted by Habermas to pastoral guidance. He regards it as important so long as ethical criteria are proposed to help issue a well thought out and responsible opinion. And the final, and perhaps most important, difference lies in the basic understanding of the relation between reason and religion. Liberals have drawn a clear line of division, while Habermas defends 'Hegel's thesis that the major world religions belong to the history of reason itself' (2008a, p. 6). In this sense a Habermasian novelty emerges: 'making communicative ethics the heir to the ethical 
virtualities of religion which modern rationality has not known thus far how to make its own' (Mate 2008, p. 30).

Two points divide the Habermasian position from that of the reformists. Firstly, and most importantly, Habermas is in favour of using religious arguments in the preparliamentary public-political sphere. He requires these arguments to pass through a process of 'reflexive self-criticism'. However, he also thinks that a cooperative effort should be made by believers and non-believers to bring about translation into a common language. Thus, he argues that, 'whereas citizens of faith may make public contributions in their own religious language only subject to the translation proviso, by way of compensation secular citizens must open their minds to the possible truth content of those presentations and enter into dialogue, so that religious reasons might well emerge in the transformed guise of generally accessible arguments. Citizens of a democratic polity owe one another good reasons for their political positions' (Habermas 2008a, p. 132).

The second rupture occurs because Habermas, while conceding a relevant role to religious reasons via the reflexive self-critical process within the political-public sphere, does not do so in the political-juridical realm. He suggests that political legislators should abstain from using religious arguments which have not been translated. He argues: 'What is illegitimate is the violation of the principle of the neutrality of the exercise of political power which holds that all coercively enforceable political decisions must be formulated and be justifiable in a language that is equally intelligible to all citizens... The democratic procedure owes its power to generate legitimacy to its deliberative character in addition to the fact that it includes all participants; for the justified presumption of rational outcomes rests on this in the long run' (Habermas 2008a, p. 134).

By examining the points of agreement and disagreement between liberal and reformist arguments, respectively, and deliberative-discourse arguments, we note that they arise in large part due to the different concerns at stake. The liberals, for their part, are concerned that religion continues to enjoy privileges and exemptions not only in the public but also in the political sphere in democratic countries. Their fear is that religion 
would use such loopholes to seek to dominate the political sphere once again. Deliberative democracy is more interested in the possible contribution of religion to a rational construction of ethics and politics. Reformists also want religious viewpoints to be taken into account, both in the processes of political-public deliberation and, on occasion, as the exemption to the law, because of the effect on constitutional principles as well as on civil rights.

This clash of perspectives allows us to assert that the Habermasian proposal opens the possibility of going beyond the conflict between multiculturalists and neutralists sparked by the idea of 'rule-and-exemption'. In accordance with Habermas's line of argument, and rethinking the relation between reason and religion in the light of our post-secular context and conscience, it is possible to conceive of exemptions as justified - in some cases -.so as to allow the role of churches and religious organisations as 'communities of interpretation. We will expand on this point in the next section.

\section{Conclusion: from negotiation to recognition and deliberation}

Our proposal is to explore a middle road which has already been pointed out by other authors, though they bring different baggage with them. Martha Minow, for example, undertakes a rigorous study of the responses provided by North American constitutionalism to the question of whether religious groups should be exempt from civil rights laws. She shows that despite two antagonistic responses in the philosophical discourse, the history and analysis of the answers produced at national, state and local level in North America demonstrate the promise of a third option.

The two conflicting positions are, on the one hand, a categorical 'no one, not even religious organizations, should be exempt from civil rights laws' and, on the other, a clear 'religious groups should be exempt from regulations that otherwise would coerce their members to violate their religious beliefs'. Minow highlights in her study that, in responses in to the United States to petitions for exemptions to the law, there is no clear, unequivocal reply. In fact, her work demonstrates that 'religious groups largely receive no exemptions from laws prohibiting race discrimination, some exemptions from laws 
forbidding gender discrimination, and explicit and implicit exemptions from rules forbidding sexual orientation discrimination’ (Minow 2007, p. 782).

Minow points to a third path between the 'categorical no' and the 'rotund yes'. This is the path of negotiation, 'especially with the strategy of identifying solutions that satisfy the religious groups and the civil rights advocates'. This negotiation implies, on the one hand, a cost-benefit analysis with respect to the overall good to civil and political society, and on the other, the use of attitudes of respect, flexibility, and humility that 'can help generate new answers beyond 'exemption' and 'no exemption' when religious principles and civil rights laws collide' (Minow 2007, p. 844). She adds that ' $(\mathrm{t})$ he collision between a religious group and civil rights advocates resembled a clash of absolutes’ (Minow 2007, p. 839).

Although this is an interesting discussion of the possibility of recovering political-public virtues such as respect, flexibility and humility, our view is that, in a negotiating context, such virtues are of little use, given the inequality of conditions between interlocutors. Moreover, one must take into account the fact that these virtues must be learned, and cannot be imposed through laws or politics.

We consider these virtues to be innate. They gain motivational strength to act in cultural and religious communities. In this sense, a deliberative democracy cannot dispose of its functional and motivational role in generating meaning. The key lies in having such virtues placed in the service of the search for reciprocal recognition both in the political sphere and in pre-parliamentary discourses in the public-political realm. This mutual recognition implies the introduction of controversial questions into public discourse, so that both secular and religious arguments can be made. As Habermas explains: 'Mutual recognition implies, among other things, that religious and secular citizens are willing to listen and to learn from each other in public debates' (2008a, p. $3)$.

The only way out is to take a path of 'mutual learning', on which the believer as well as the non-believer must undertake a cooperative task and translate his arguments into a language shared by and accessible to all. The door is open so that, in cases where translation is impossible, the matter will not disappear from the public-political sphere, 
though it will not be able to pass into the political-juridical sphere until the process of mutual learning is complete.

Our proposal is that, in order to judge whether the discourses satisfy the principles of discourse ethics mentioned in this article - in order, in other words, to respond to the question of how well these discourses comply with the moral expectations that any person may hold - four conditions must be met:

1) Inclusion and public character: no person who may make a relevant contribution in relation to the controversial validity may be excluded.

2) Equality in communication: all interlocutors are to be granted the same opportunities to express themselves regarding the issue at hand.

3) Exclusion of trickery and illusion: participants must believe in what they say.

4) Lack of coercion: communication must be free of restrictions, as these prevent the best argument from emerging and predetermine the outcome of the discussion (Habermas 1998, 3-46 and Habermas 2008a, p. 50).

Thus, if deliberation about controversial questions in the political and the publicpolitical sphere is a necessary condition, within a democracy, for the definition of norms and principles acceptable to any human being for the governing of their political and public life, it is not a sufficient condition for civic solidarity among members. In other words, political virtues must be rooted in concrete contexts if they are to take hold. Blocking the potential of religion (for example by reducing opportunities for religious education), or denying public recognition of citizens' religious identity would be a grave error in constructing a democratic ethos. However, granting privileges and exemptions without carefully examining arguments and justifications could lead to ethically and politically unjustified treatment.

In this vein, it might be said that, faced with demands for exemption for churches as 'communities of interpretation' and as 'motivational sources', liberal democracies should take a deliberative path. For example, participation should be 
possible in the great debates which Western pluralist societies have held openly for decades, under the conditions set out in this article. Participation is not a guarantee that an exemption will be granted but, in some cases, it could happen. In our view, this could apply in the case of at least these requests for exemption: adjustment of the school curriculum to teach religious values and a framework of tax relief to churches so as to ensure that organisation (this is important to maintain lively religious communities, which may otherwise disappear or face hardship); exemptions to dress codes and even to some rules related to school menus (which are a form of public recognition of citizens together with their religious identity). The key point is the promotion of public and political deliberation on this and other topics, where the process of 'complementary learning' becomes a touchstone for the building of a shared democratic ethos, and, accordingly, where the potential of churches as 'communities of interpretation' is fully recognised.

To conclude: exemptions in this approach are considered as a means to allow churches and religious organisations to flourish, and to recognise their crucial role in the public sphere and in deliberative democracy as source of values and motivation. We believe that this contributes to a new perspective on the relationship between religion and the law, the value of which we should not underestimate in our western pluralistic societies.

\section{References}

Audi, Robert and Nicholas Wolterstorff. 1997. Religion in the public square. The place of religious convictions in liberal debate. London: Rowman \& Littlefield.

Audi, Robert. 1989. The separation of church and state and the obligations of citizenship.. Philosophy and Public Affairs 18: 259-96

Audi, Robert. 1997. Liberal democracy and the place of religion in politics. In Religion in the public square. The place of religious convictions in liberal debate, ed. Robert Audi and Nicholas Wolterstorff. London: Rowman \& Littlefield, 1-66 
Bader, Veit. 1999. Religious pluralism: secularism or priority for democracy? Political Theory 27: 597-633.

Bader, Veit. 2003. Religious diversity and democratic institutional pluralism. Political Theory 31: 265-294.

Bader, Veit. 2003. Taking religious pluralism seriously: arguing for an institutional turn. Introduction. Ethical Theory and Moral Practice 6: 3-22.

Barry, Brian. 2000. Culture and equality. Cambridge: Polity Press.

Bedi, Sonu. 2007. Debate: What is so special about religion? The dilemma of the religious exemption. Journal of Political Philosophy 15 (2): 235-249.

Bird, Colin. 1996. Mutual respect and neutral justification. Ethics 197: 61-95

Bou-Habib, Paul. 2006. A theory of religious accommodation. Journal of Applied Philosophy 23 (1): 109-126.

Bradley, Gerard V. 1991. Beguiled: free exemptions and the siren song of liberalism. Hofstra Law Review 20: 245-319.

Chambers, Simone. 2007. How religion speaks to the agnostic: Habermas on the persistent value of religion. Constellations 14 (2): 210-223.

Conill, Jesús. 2007. Racionalización religiosa y ciudadanía postsecular en perspectiva habermasiana. Pensamiento: Revista de investigación e información filosófica 63 (238): 571-581.

Cooke, Maeve. 2007. 'A secular state for a postsecular society? Postmetaphysical political theory and the place of religion. Constellations 14 (2): 224-238.

Cortina, Adela. 1993. Ética aplicada y democracia radical. Madrid: Tecnos.

Cortina, Adela. 1995. Ética civil y religión. Madrid: PPC.

Cortina, Adela. 1998. Hasta un pueblo de demonios. Ética pública y sociedad. Madrid: Taurus.

Cortina, Adela. 2001. Alianza y contrato. Política, ética y religión. Madrid: Trotta. 
Evans, Mark. 2004. Pluralising liberalism, liberalising pluralism. Res Publica 10: 449460.

Galeotti, Anna Elisabetta. 1993. Citizenship and equality: The place for toleration. Political Theory 21 (4): 585-605

Greenawalt, Kent. 1990. Religious convictions and political choice: Some further thoughts. DePaul Law Review 39: 1.019-1.046

Gutmann, Amy and DerekThompson. 1990. Moral conflict and political consensus. Ethics 101 (1): 64-88.

Habermas, Jürgen. 1972, Knowledge and human interests. Boston: Beacon Press.

Habermas, Jürgen. 1975, Legitimation crisis. Boston: Beacon Press.

Habermas, Jürgen. 1987. The theory of communicative action: Volume 2. Boston: Beacon Press.

Habermas, Jürgen. 1996. Between facts and norms. Contributions to a discourse theory of law and democracy. Cambridge: Polity Press.

Habermas, Jürgen. 1998. The inclusion of the other. Studies in political theory. Cambridge: The MIT Press.

Habermas, Jürgen. 2008a. Between naturalism and religion. Philosophical essays. Cambridge: Polity Press.

Habermas, Jürgen. 2008b. La voz pública de la religión. Respuesta a Flores d’Arcais. Claves de razón práctica 180:4-12.

Hollenbach, David. 1993. Contexts of the political role of religion: Civil society and culture. San Diego Law Review 30: 877-901

Jones, Peter. 2004. Introduction: law and disobedience. Res Publica 10: 319-336.

Kant, Immanuel. 1988. Crítica de la razón pura. Madrid: Alfaguara.

Lafont, Cristina. 2007. Religion in the public sphere: Remarks on Habermas's conception of public deliberation in postsecular Societies. Constellations 14 (2): 239-259. 
Levy, Jacob T. 1997. Classifying cultural rights.' InEthnicity and Group Rightsed. Ian Shapiro and Will Kymlicka.. Nomos XXXIX. New York: New York University Press, 22-66.

Locke, John. 1999. Carta sobre la tolerancia. Ensayo y Carta sobre la tolerancia. Madrid: Alianza.

Marshall, William P. 1990. The case against the constitutionally compelled free exercise exemption. Case Western Law Review 40 (2): 357-412.

Mate, Reyes. 2008. El debate Habermas - Flores d’Arcais: la religión en una sociedad postsecular. Claves de razón práctica 181: 28-33.

Minow, Martha. 2007. Should religious groups be exempt from civil rights laws? Boston Collage Law Review 48 (781): 781-849.

Noonan, Jeff. 2005. Modernization, rights, and democratic society: The limits of Habermas’s democratic theory.’ Res Publica 11: 101-123.

Quong, Jonathan. 2004. Disputed practices and reasonable pluralism. Res Publica 10: 4367.

Rawls, John. 1996. Liberalismo político. Barcelona: Crítica.

Rawls, John. 1999. El derecho de gentes y 'Una revisión de la idea de razón pública'. Barcelona: Crítica.

Smith, William. 2004. Democracy, deliberation and disobedience. Res Publica 10: 353377.

Weithman, Paul. J. 1991. The separation of church and state: Some questions for Professor Audi. Philosophy and Public Affairs 20 (1): 52-65.

Weithman, Paul. J. 1995. Contractualist liberalism and deliberative democracy.

Philosophy and Public Affairs 24 (4): 314-343. 